Kenya, and Tanzania. A three-year grant has been made by the Ford Foundation to establish the centre which will be directed by Dr. Angela Molnos, who also holds a bursary of the Fritz Thyssen Foundation of West Germany. Dr. Molnos had earlier made a study of social researches in East Africa over the period I $954-63$ and the results were published in her book Die sozialwissenschaftliche Erforschung Ostafrikas 1954-1963 (Kenya, Tanganyikal Sansibar, Uganda) (Springer, for Ifo-Institut, München, 1965) which gives a comprehensive bibliography for this period together with a commentary on the scope of researches listed under tribal groups, topics, and territories. Information and inquiries should be addressed to: Dr. Angela Molnos, c/o The Ford Foundation, P.O. Box 108 I, Nairobi, Kenya.

\title{
Institute of Ethiopian Studies: Social Research Seminar
}

ThE Institute of Ethiopian Studies of Haile Selassie I University held its first annual Social Research Seminar from 20 to 23 April, under the general chairmanship of Dr. I. M. Lewis of University College London. It received assistance from the British Ministry of Overseas Development, and was planned by Dr. Richard Pankhurst and Professor J. Comhaire. The Seminar was concerned with the North-East African region and received reports on field work in Somalia and the Sudan as well as in Ethiopia, being attended by anthropologists currently engaged in field-work and by members of the Haile Selassie I University's Faculties of Arts, Law, Medicine, Business Administration, and the Institute of Ethiopian Studies, as well as staff of the Ministry of Community Development and Public Health. Papers were given by Dr. D. Hecht on 'Sacred kingship in Africa', Ato Fekadu Gedamu on the 'Social organisation of the Kistane Gurage', J. Stauder on 'The social organisation of the Mahangir', Dr. I. M. Lewis on 'Possession cults in Northern Somalia', Mr. A. Orent on 'The Doce cult in Kaffa', Virginia Luling on 'Spirit-possession cults in Mogadiscio', Ato Terefe Walde Tsadik on 'The Muyat cult in Shoa', R. Hallpike on 'Status of craftsmen among the Konso', Mr. M. Cittadini, on 'Kunama marriage', and J. Lisowski on 'Biometrics of N.E. African migrations'. Development papers were given by P. Sand on 'Law as a factor of social change', G. Savard on 'Social factors in development', M. de Young on 'Markets in Ethiopia', S. Messing on 'Medical attitudes and practices in Ethiopia' and R. Bahar on 'Rural housing in Ethiopia'.

\section{The Register of Current Research on Ethiopia and the Horn of Africa}

THis Register, published by the Institute of the Ethiopian Studies of Haile Selassie I University, is edited by Richard Pankhurst and S. Chojnacki and lists all scholars and current research workers dealing with the Horn of Africa, with information on their publication plans.

Offprints of 'Notes and News' are available on a subscription basis as from January 1966 . They are printed on one side of the paper only so that the individual entries may be mounted on cards to form a card index. The annual subscription is Ios. (\$1.50; F 6.90), post free. 